УДК 655.3.022.11

\title{
СУЧАСНИЙ СТАН ТЕХНОЛОГІЙ ДРУКУВАННЯ В УКРАЇНІ
}

( К. І. Савченко, аспірантка, О. В. Зоренко, К.Т.н., доцент, Т. В. Розум, к.т.н., доцент, О. М. Величко, д.т.н., професор, НТУУ «КПІ», Київ, Україна

\section{Проанализировано современное состояние технологий печатания в Украине, определена степень распределения типографий по регионам Украины и способам печати, которые в них используются. Систематизированы инсталляции печатного оборудования.}

The contemporary state of printing technology in Ukraine was analyzed. The degree of distribution of printing companies in the regions of Ukraine and ways of printing, which they used were studied. Systematized installation of printing equipment.

\section{Постановка проблеми}

Виробництво поліграфічної продукції націлено на реалізацію найсміливіших і оригінальних ідей. Сучасний український поліграфічний ринок пропонує широкий спектр послуг, витратних матеріалів, обладнання для виготовлення найрізноманітнішої поліграфічної продукції. Ексклюзивні видання, високоякісна рекламна продукція, креативне паковання складної конструкції - це далеко не повний перелік продукції, яка виробляється в Україні. Завдяки гібридним та УФ-технологіям, опорядженню продукції металізованими фарбами, лакуванню, складним видам висікання, комбінуванню традиційних, матових і мерехтливих лаків, шестифарбового друку, металізованих та УФ-фарб, можливе перетворення звичайної продукції різноманітного призначення в оригінальну. Особливо популярними останнім часом $€$ гібридні та УФ-технології.
Гібридні технології в широкому розумінні цього нового терміну, усталеного в останнє десятиліття, тлумачиться як поєднання в одному виробничому процесі двох-трьох варіантів діаметрально протилежних типів технологічних рішень для створення оригінального, або складного за конструкцією виробу.

Однак, інформація щодо відображення місця технологій друкування у сучасному ВПК України, практично відсутня. Тож актуальність визначення тенденцій поліграфічного ринку України є очевидною.

\section{Аналіз попередніх досліджень}

Державний комітет статистики хоча і проводить постійний аналіз кількості промислових підприємств за видами діяльності, які працюють на території держави, однак не відображає ключових тенденцій, проблем і перспектив розвитку поліграфічної діяльності в Україні. 
Лише в роботі [1] відслідковано зміну кількості та структуру підприємств за формами власності впродовж 2001-2005 рр., їх розподіл за регіонами країни, розглянуто динаміку обсягу виготовленої продукції за окремими групами, дана оцінка ринку друкованої продукції за станом на 2005 р., наведено фінансові результати тощо.

Також проводилися дослідження ринкових концепцій поліграфічного виробництва, висвітлювалися проблеми та перспективи поліграфічної галузі за результатами анкетування [2-4], де визначалася структура поліграфічного ринку України, досліджувалися проблематичні питання, встановлювалися шляхи їх вирішення.

На світовому рівні відомі роботи $[5,6]$ стосовно розвитку тенденцій способів друку на першу декаду XXI ст. Однак, деякі дані вже втратили свою актуальність, а прогнози щодо роз- витку новітніх технологій, зокрема гібридних та УФ-технологій безпосередньо пов'язані зі станом галузі, оцінка якої характеризує ступінь розвинутості матеріально-технічного забезпечення.

Нині відбуваються зміни у характері замовлень, що відповідають потребам ринку. Відповідно це призводить до змін у розподілі способів друку, поліграфічної продукції.

Слід визначити наскільки активно нові технології впроваджуються в Україні. Для цього варто проаналізувати способи друку й технологічне оснащення, які використовуються в Україні, а також світові тенденції виробництва друкованої продукції.

\section{Мета роботи}

Мета роботи полягає у аналізі тенденцій розвитку способів друку, обладнання й витратних матеріалів в Україні.

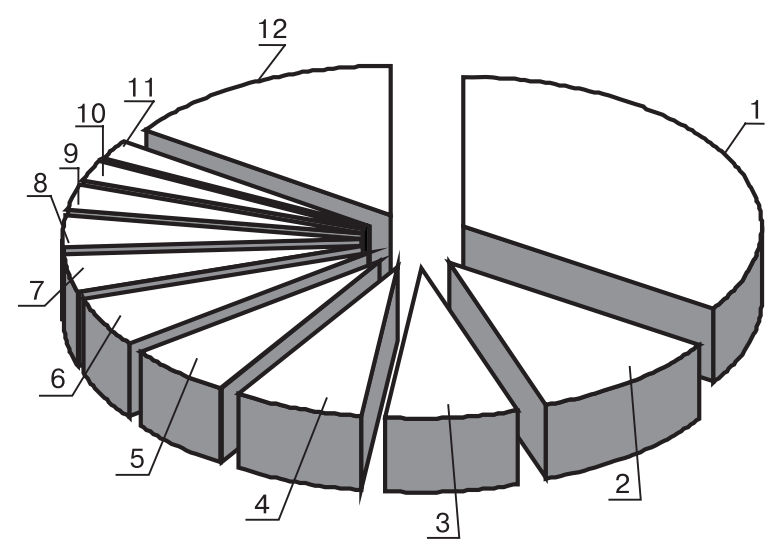

Рис. 1. Діаграма розташування друкарень по регіонах України:

1 - Київська (35 \%); 2 - Харківська (11\%); 3 - Дніпропетровська (7 \%); 4 - Донецька (7 \%); 5 - Львівська (6 \%); 6 - Одеська (5 \%); 7 - Крим, AP (4 \%); 8 - Запоріжська (3 \%); 9 - Полтавська (3 \%); 10 - Луганська (2\%); 11 - Вінницька (2 \%); 12 - інші (15\%), (менше ніж 1 \% на область) 


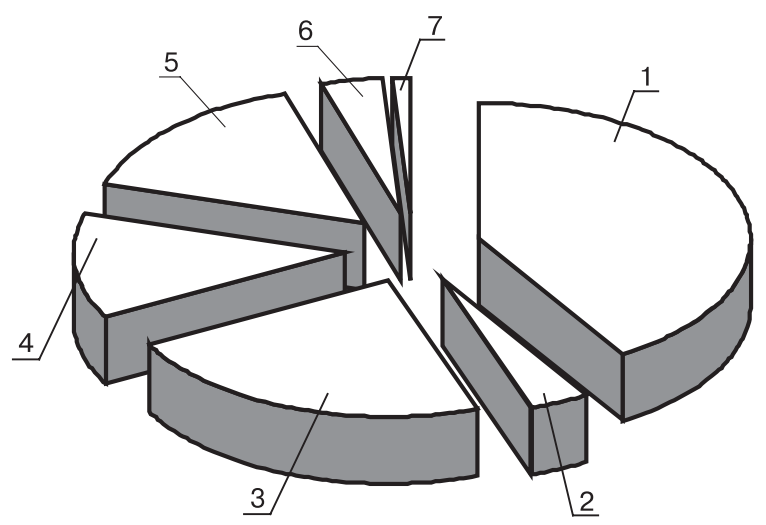

Рис. 2. Діаграма використання способів друку в друкарнях України за станом на 2010 рік: 1 - офсетний $(41 \%)$; 2 - флексографічний (3,8 \%); 3 - цифровий (22,3 \%); 4 - трафаретний (12,5\%); 5 - струминний із застосуванням широкоформатних принтерів (15,7 \%);

6 - тамподрук (3,5\%); 7 - високий $(1,5 \%)$

\section{Результати проведених досліджень}

Для визначення ступеня розподілу друкарень по регіонах України (рис. 1) та способах друку, які в них використовуються (рис. 2), було використано анкетні дані друкарень, які збиралися колективом редакції журналу «Print Plus» впродовж підготовки довідника «Поліграфія України 2010-2011» $[4,7]$.

За результатами опрацювання 429 анкет визначено стан і тен-

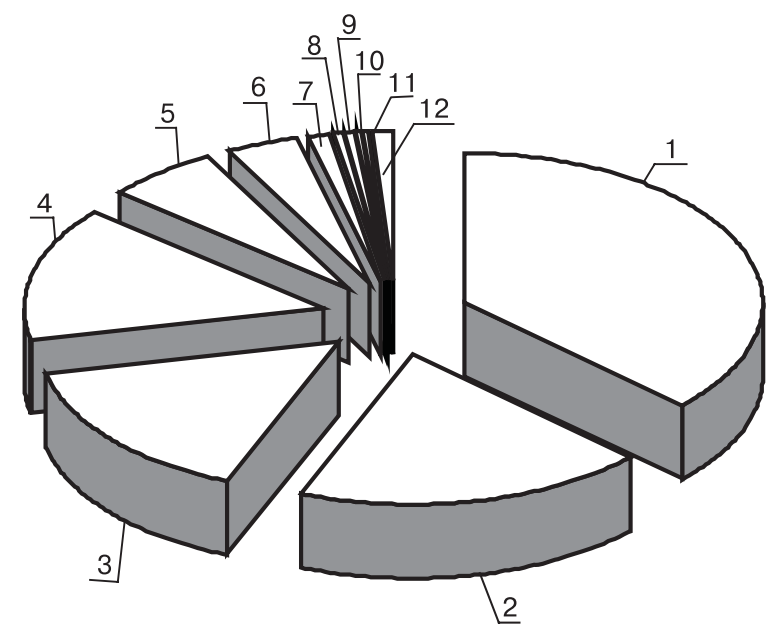

Рис. 3. Парк аркушевих офсетних машин в друкарнях України: 1 - Adast (37 \%); 2 - Heidelberg (19,2 \%); 3 - KBA (15,6\%); 4 - manroland (14,4 \%);

5 - Ryobi (6 \%); 6 - Hamada (4 \%); 7 - Shinohara (1\%); 8 - Komori $(0,6 \%) ; 9$ - Mitsubishi $(0,5 \%) ; 10$ - Sakurai $(0,3 \%) ; 11$ - TOKO (0,3\%); 12 - інші $(1,1 \%)$ 


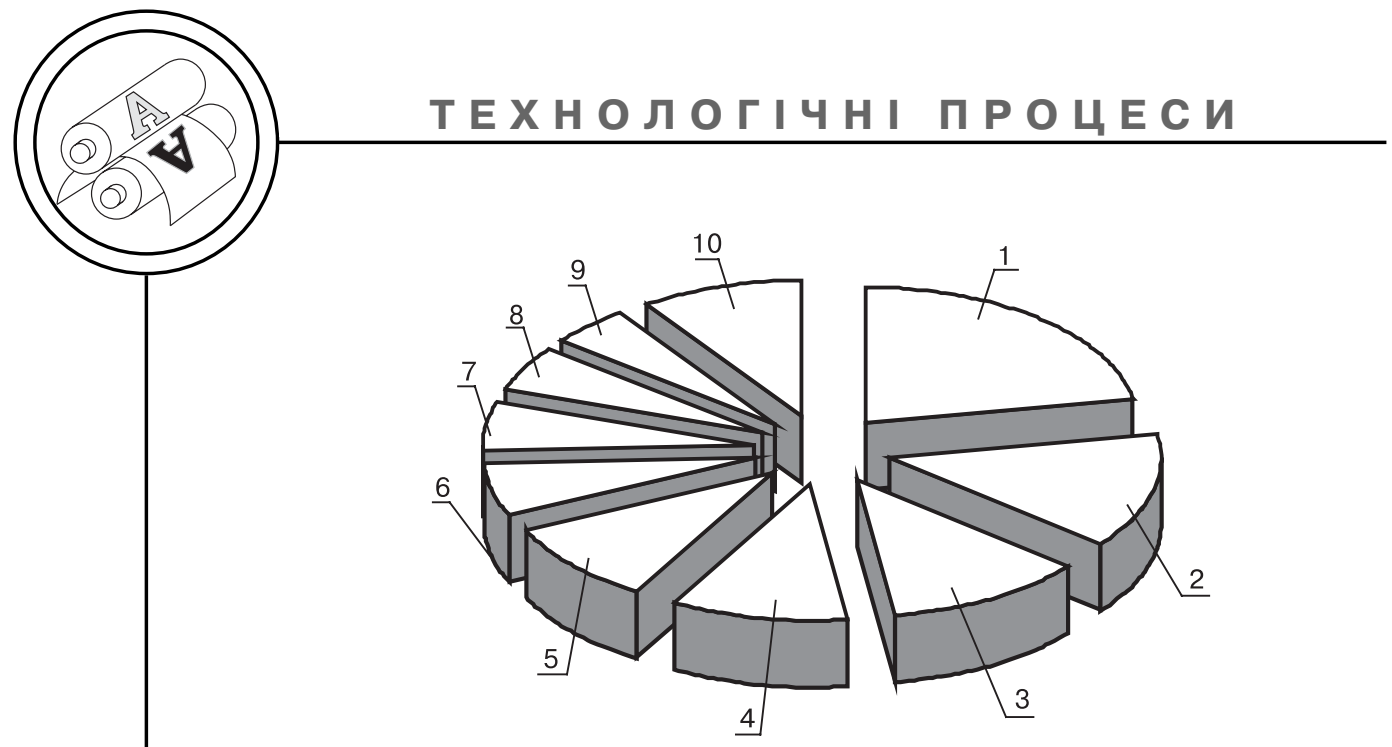

Рис. 4. Процентне співвідношення рулонного офсетного обладнання, яке інстальоване в друкарнях України: 1 - Manugraph (22,2 \%); 2 - Solna

(13,7 \%); 3 - manroland (11,8\%); 4 - Heidelberg (10,5 \%); 5 - KBA (9,8 \%); 6 - Zircon (6,5\%); 7 - ПОГ (5,9\%); 8 - Goss (5,2 \%);

$$
9 \text { - Rondoset (4,6 \%); } 10 \text { - інші (9,8\%) }
$$

денції інсталяцій аркушевих (рис. 3) та рулонних (рис. 4) офсетних машин, зокрема відслідковано інсталяції офсетного аркушевого обладнання впродовж 2006-2010 років (рис. 5, 6).

Як видно з рис. 1, найбільша кількість друкарень розташована саме в індустріально розвинених регіонах України, а най- більш поширеним способом друку є плоский офсетний (рис. 2).

Тенденції розвитку способів друку увиразнилися за останнє десятиліття, завдяки тотальній автоматизації та комп'ютеризації поліграфічного обладнання, поширенню технологій з використанням УФ- і металізованих

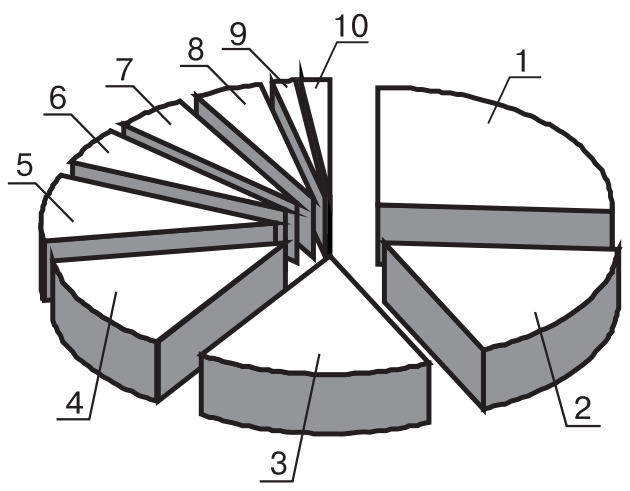

Рис. 5. Процентне співвідношення аркушевого офсетного обладнання, яке інстальоване в друкарнях України впродовж 2006-2010 pр.: 1 - man-

roland (26,7\%); 2 - Heidelberg (17,6\%); 3 - KBA (16,5\%); 4 - Ryobi (14\%); 5 - Adast (9,4\%); 6 - Hamada (5,1\%); 7 - Shinohara (5,1\%); 8 - Komori (5 \%); 9 - Mitsubishi (1,6 \%); 10 - інші (2 \%) 
фарб, гібридних технологічних процесів, які все активніше впроваджуються у виробництво.

Знаковим є збільшення частки цифрового друку разом із струминним і зменшення високого друку. Однак, згідно світових прогнозів [5, 6], за якими частка глибокого друку сягає $15 \%$ і характерна для виготовлення гнучкого паковання 3 полімерної плівки, не знайшла відображення в отриманих нами результатах. Хоча відомо, що навіть у Києві є декілька підприємств, які застосовують виключно глибокий друк. Достатньо значна частка трафаретного друку в Україні (12,5 \%), що відрізняється від світових тенденцій, проаналізованих в роботах $[5,8,9]$. Тобто, наведені на рис. 3 дані характеризують строкату картину перехідного періоду від тотального панування плоского офсетного і високого у 90-х роках минулого століття до переважання цифрових технологій. Доречно зауважити, що ринок продукції також змінився переважають паковання, елітна книжкова продукція, рекламна і етикеткова продукція, а також змінилися наклади - їх обсяги не переважають середніх 3-5 тис. Тільки для шкільних підручників тиражі залишаються стабільно високими - до 300 тис. примірників. Збільшилася частка різноманітної продукції накладом 1-500 примірників.

Тож використання гібридних технологій, а також УФ- та металізованих фарб $є$ не випадковим, а закономірним явищем. Об'єктом гібридних технологій $€$ елітна продукція, яка виробляється невеликими накладами. У зв'язку з цим виникають проб- леми неефективної експлуатації високопродуктивного спеціалізованого обладнання внаслідок обмеженої кількості замовлень. Для застосування гібридної технології може використовуватися машина секційної побудови, оснащена п'ятьма або більше друкарськими секціями і лакувальною секцією, а також подвійною подовженою прийомкою. Як видно $з$ рис. 3 в Україні переважають машини середнього формату «ADAST», що $є$ закономірним, оскільки цей виробник забезпечує раціональне співвідношення «ціна-якість». Проте лише декілька друкарень в Україні можуть заявити, що вони використовують саме гібридні технології і відповідне високотехнологічне обладнання. Однак, все ж таки прослідковується тенденція до встановлення в останні роки саме нового, високоавтоматизованого обладнання, яке відповідає сучасним вимогам ринку (рис. 6).

Для визначення пропозицій постачальників витратних матеріалів в Україні стосовно продажу фарб було проаналізовано
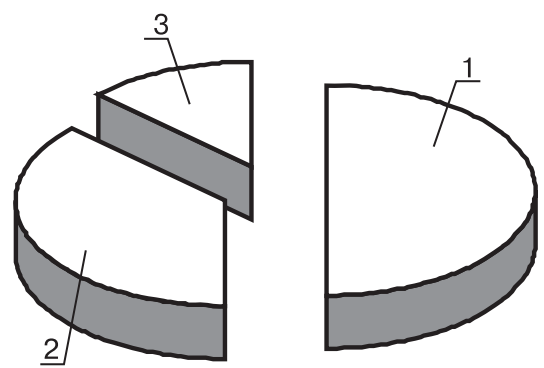

Рис. 6. Процентне співвідношення інсталяцій за 2006-2010 рр. нового (починаючи з 2000 р.), старого (до 2000 р.) та б/у обладнання: 1 - нове (50 \%); 2 - старе (37\%); $3-$ б/у обладнання (13\%) 


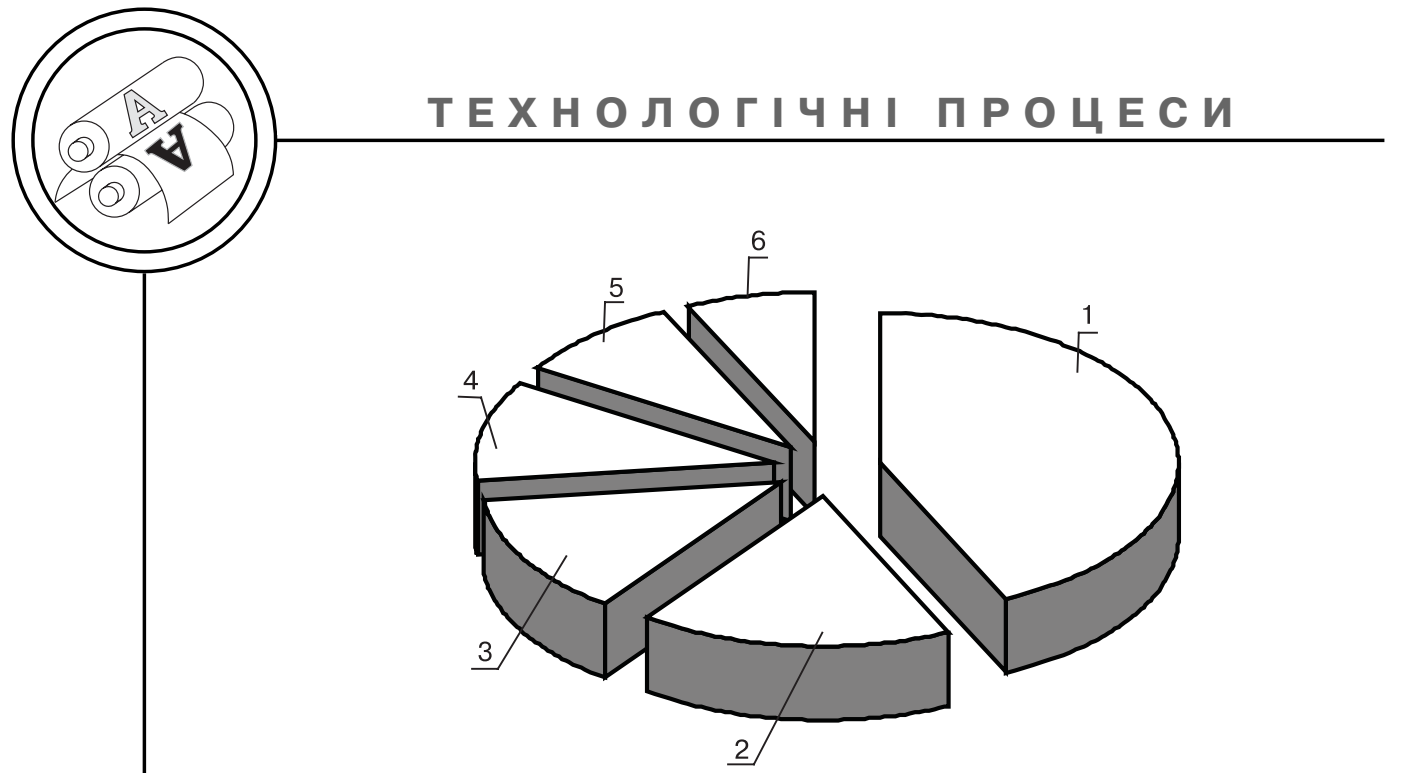

Рис. 7. Розподіл постачальників фарб по регіонам України: 1 - Київська (43 \%); 2 - Харківська (17\%); 3 - Львівська (13\%); 4 - Дніпропетровська (11\%); 5 - Одеська (9\%); 6 - Донецька (7\%)

відкриті джерела доступу до даної інформації та побудовані діаграми процентного співвідношення. Обробка інформації, отриманої шляхом анкетування та аналізу відкритих інформаційних джерел, дала змогу проаналізувати проблему впровадження гібридних технологій в Україні та оцінити ринок з технологічного боку.
Постачальники витратних матеріалів зосереджені саме в індустріально розвинених регіонах України (рис. 7) і переважають пропозиції фарб для офсетного способу друку (рис. 8).

Як видно з результатів дослідження парк офсетного обладнання, інстальованого в Україні, асортимент витратних матеріалів, зокрема фарб, достатньо

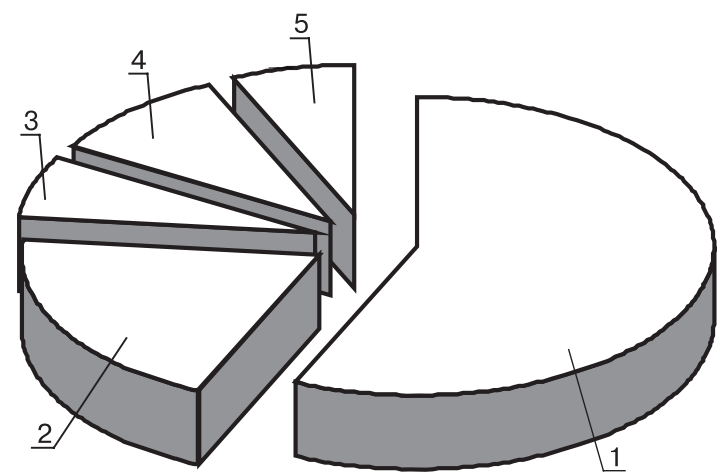

Рис. 8. Пропозиції фарб на ринку України: 1 - фарби для офсетного друку (56 \%); 2 - фарби для флексографічного друку (20 \%); 3 - фарби для глибокого друку (7 \%); 4 - фарби для трафаретного друку (10 \%); 5 - фарби для тамподруку (7 \%) 
широкий. Лідируючі позиції займає офсетний спосіб друку і відповідно фарби для офсетного друку $€$ найбільш поширеними серед пропозицій постачальників. Однак, стосовно впровадження гібридних технологічних процесів існує багато суперечностей. Досить важко знайти на ринку України гібридні фарби, а стверджувати про здатність до оздоблення продукції за допомогою гібридних технологій можуть зовсім небагато українських друкарень. Пере- важна більшість все ж таки поки що за традиційні технології, які $\epsilon$ менш проблематичними.

\section{Висновки}

1. Проведений аналіз поліграфічного ринку сприяв виявленню тенденцій розвитку поліграфічної галузі.

2. Цікавість до новітніх гібридних та УФ-технологій зростає з кожним роком, тож слід очікувати, що і в Україні незабаром ці технології набудуть ширшого застосування.

1. Дурняк Б. В. Видавнича справа та поліграфічна діяльність в Україні / Б. В. Дурняк, А. М. Штангрет, О. В. Мельников, Я. М. Угрин. - Львів : УАД, 2009. - 150 с. 2. Подолюк Ю. Зворотний зв'язок / Ю. Подолюк, О. Величко // Друкарство. - 1996. - С. 48. 3. Зайцева О. Деякі проблеми ринку витратних матеріалів для поліграфії / О. Зайцева // Друкарство. - 2003. - № 1. - С. 74-77. 4. Офсетная картина. Возможность покупки новой техники снизилась, но рынок не умер // Print Plus: бумага и полиграфия. - 2009. № 3. - C. 40-48. 5. Kipphan H. Handbook of print media: technologies and production methods. - Berlin; Heidelberg; New York; London : Springer, 2001. P. 130-142. 6. [Електронний ресурс]. - Режим доступу : http://seyboldpublications.com/. 7. Справочник «Полиграфия Украины 2010-2011»/ [под. ред. Агаркова И. В.]. - К. : Стандарт, 2010. - 460 с. 8. Величко О. М. Опрацювання інформаційного потоку взаємодією елементів друкарського контакту / Олена Величко [Текст] : Монографія. - К. : ВПЦ «Київський університет», 2005. - 264 с. 9. Хохлова Р. А. Лакування у друкарсько-обробному процесі / Розалія Хохлова, Олена Величко [Текст] : Монографія. - К. : ВПЦ «Київський університет», 2010. - 136 с.

$$
\begin{array}{r}
\text { Рецензент - В. В.Степанець, к.т.н., } \\
\text { доцент, НТУУ «КП।» }
\end{array}
$$

